\title{
TMEM45B Gene
}

National Cancer Institute

\section{Source}

National Cancer Institute. TMEM45B Gene. NCI Thesaurus. Code C152008.

This gene may play a role in cell proliferation and migration. 